\title{
Infectious Agents As Markers of Human Migration toward the Amazon Region of Brazil
}

\author{
Ricardo Ishak*, Luiz F. A. Machado, Izaura Cayres-Vallinoto, \\ Marluísa de O. Guimarães Ishak and Antonio C. R. Vallinoto \\ Virus Laboratory, Institute of Biological Sciences, Federal University of Para, Belem, Brazil
}

\section{OPEN ACCESS}

Edited by:

John W. A. Rossen,

University Medical Center Groningen,

Netherlands

Reviewed by:

Gabriele Margos,

Bayerisches Landesamt für

Gesundheit und

Lebensmittelsicherheit (LGL),

Germany

M. J. L. Coolen,

Curtin University, Australia

${ }^{*}$ Correspondence:

Ricardo Ishak

rishak@ufpa.br

Specialty section:

This article was submitted to

Infectious Diseases,

a section of the journal

Frontiers in Microbiology

Received: 28 December 2016 Accepted: 17 August 2017

Published: 31 August 2017

Citation

Ishak R, Machado LFA, Cayres-Vallinoto I, Guimarães Ishak MO and Vallinoto ACR (2017)

Infectious Agents As Markers

of Human Migration toward

the Amazon Region of Brazil.

Front. Microbiol. 8:1663.

doi: 10.3389/fmicb.2017.01663
Infectious agents are common companions of humans and since ancient times they follow human migration on their search for a better place to live. The study of paleomicrobiology was significantly improved in its accuracy of measurement with the constant development of better methods to detect and analyze nucleic acids. Human tissues are constantly used to trace ancient infections and the association of anthropological evidences are important to confirm the microbiological information. Infectious agents which establish human persistent infections are particularly useful to trace human migrations. In the present article, the evidence of infection by viral agents such as human T-lymphotropic virus 1, human T-lymphotropic virus 2, human herpes virus-8, JC virus, and a bacterium, Chlamydia trachomatis, was described using different methodologies for their detection. Their presence was further used as biomarkers associated with anthropological and other relevant information to trace human migration into the Amazon region of Brazil. The approach also evidenced their microbiological origin, emergence, evolution, and spreading. The information obtained confirms much of the archeological information available tracing ancient and more recent human migration into this particular geographical region. In this article, the paleomicrobiological information on the subject was summarized and reviewed.

Keywords: biomarkers, infectious agents, epidemiology, human migration, Amazon

\section{INTRODUCTION}

Viral agents are commonly associated to infections which are able to trace human ancient and recent migrations all over the world. In the early history of civilization small human groups started to move around the world to find safer environment and food. Their traveling into previously unknown areas brought also the interaction with new infectious agents. Recent human spread as a consequence of wars, famine, disasters, and many other modern dangers also carried old and new agents with greater or less chance to spread and cause severe prejudice.

It was not until recently that we could seriously evaluate the effect of emerging infectious agents in the course of the human migration around the world. The improvement of nucleic acid analysis facilitated the detection of ancient molecules of infectious agents which was an enormous step toward the delineation of historical patterns of infections and ancient migrations of human populations. The study of paleomicrobiology was significantly advanced with the detection of the DNA of Mycobacterium tuberculosis in an ancient skeleton which progressed with the identification 
of infectious agents and their geographical spreading, as they were related to their respective paleo specimens (Spigelman and Lemma, 1993; Raoult and Drancourt, 2008; Djelouadji et al., 2011).

Dental pulp specimens allowed the recovery of human immunodeficiency virus (HIV-1) integrated DNA from fibroblasts of an AIDS patient (Glick et al., 1991), as well as the DNA of Yersinia pestis from skeletons dated from the 14th, 16th, and 18th centuries (Drancourt et al., 1998; Raoult et al., 2000). Human papillomaviruses and human T-lymphotropic virus 1 (HTLV-1) genetic materials were detected in tissues dated from the 4th (Li et al., 1999) and 16th (Fornaciari et al., 2003) centuries. Most of the time such approaches are better suited to viruses which generally establish persistent infections, but influenza virus (H1N1), a short replication cycle RNA virus was described in paraffin embedded biopsies from the 1918 epidemic (Reid et al., 1999). More recently, hepatitis C virus (HCV), an RNA virus which is able to establish persistence in humans without nucleic acid integration, was recovered from the dental pulp and could be used as a biomarker of past and ancient infections (Siravenha et al., 2016).

Persistence of viruses allows the application of molecular biology methods, but also of other methods; antibody detection using serological studies are indicative of the presence of the persistent virus infection. This approach coupled to molecular biology methods has allowed us to define the presence of past and old infections among specific population groups in the Amazon region of Brazil within epidemiologically closed groups of "quilombolas" (slave refugees) or native Indians and immigrants with little or no degree of miscegenation at all.

Epidemiological studies, mostly descriptive ones, were important biological tools when associated to molecular biology approaches, particularly when dealing with the recent history of specific infectious agents. Besides describing the presence of the infectious agent, it also showed the valuable importance of surveillance when detecting the recent entry of new infectious agents among human population communities. In the recent history of the study of infectious agents in the Amazon region of Brazil, there are some examples of major relevance, including the involvement of native Indians with devastating agents such as hepatitis B virus (HBV) and HIV-1 (Santos et al., 1995; Machado et al., 2006; Nunes et al., 2007).

An extensive seroepidemiological study was performed with native Indians looking for the presence of infection markers of HBV. There was one community, namely the Parakana, which was found to be free of the agent. The main characteristic was that the samples were collected within 2 weeks after the initial contact with the community (Santos et al., 1995). Few years only were necessary to show the introduction and rapid spreading of the virus in the Parakana (Nunes et al., 2007). A situation which was shown to be even more critical and distressing was shown by our laboratory concerning the recent entry of HIV-1 within an Indian community, the Tiryio, who reside in the North region of the Amazon. Retrospective seroepidemiology with historical samples from different Indian communities showed that the virus was not present until the early 1990s (Ishak et al., 1989; Zaninovic et al., 1994; Machado et al., 2006), but it was readily introduced most probably as a sexually transmitted infection (Machado et al., 2006) as usually seen with other viruses and bacteria regarding native Indian communities (Ishak and Ishak, 2001; Machado et al., 2006). These are common examples of the entry and spreading of infectious agents affecting previously epidemiologically closed and isolated Indian groups, threatened by sexually transmitted viruses and bacteria that can act as real dangers to their fertility and life span. The present article is a comprehensive review of the existent information in the field of paleomicrobiology relating the evidences of the most probable routes of how viral and bacterial infectious agents entered in the Amazon region of Brazil in ancient and more recent times together with human beings moving toward this environment.

\section{METHODOLOGICAL APPROACHES}

The initial general approach for studying viruses and their relation to human migrations investigated the presence of antibodies. As we were dealing with agents which established persistent infections the positive reactions were also a confirmation of the presence of the virus in the human host. The following step was to generate information of the genotypes, or serotypes, circulating in the Amazon region of Brazil and to associate them with previously described geographical distribution of the virus and their variants. The approach for the study of Chlamydia trachomatis was similar, as the bacterium is thought to persist in the infected persons. The evaluation of the antibody response to the serotypes indicated their spreading. The specific methodological approach for each infectious agents is reported briefly below. Specific details are described in the original publications.

\section{HTLV}

Antibodies to HTLV-1 and HTLV-2 were detected using an enzyme immune assay (and confirmed using a commercial Western blot) in serum samples of 26 native Indian tribes largely distributed in the Amazon region of Brazil (Figure 1), belonging to communities from the States of Maranhao (Urubu-Kaapor), Amapa (Galibi, Palikur, Waiapi), Roraima (Yanomami), Amazonas (Yamamadi), Rondonia (Cinta Larga, Surui, Karitiana), and Para (Wayana-Apalai, Tiryio, Assurini do Kuatinemo, Assurini do Trocara, Arara do Laranjal, Arara do Kurambe, Arara do Iriri, Gorotire, Arawete, Parakana, Munduruku, and six villages of the Kayapo, namely the Kararao, Aukre, Kubenkokre, Pukany, Kikretum, and Kokraimoro). Nucleic acid extraction was performed from positive samples in order to sequence regions of the gene env and LTR region to construct phylogenetic trees which allowed to describe the molecular subtype HTLV-2c. Detailed methodological steps were previously described (Ishak et al., 1995; Vallinoto et al., 2002).

\section{JCV}

The initial approach to investigate JC virus (JCV) in the Brazilian Amazon involved 10 native Indian tribes from the States of Para (Wai-Wai, Munduruku, Kendjam, Arara Laranjal, 


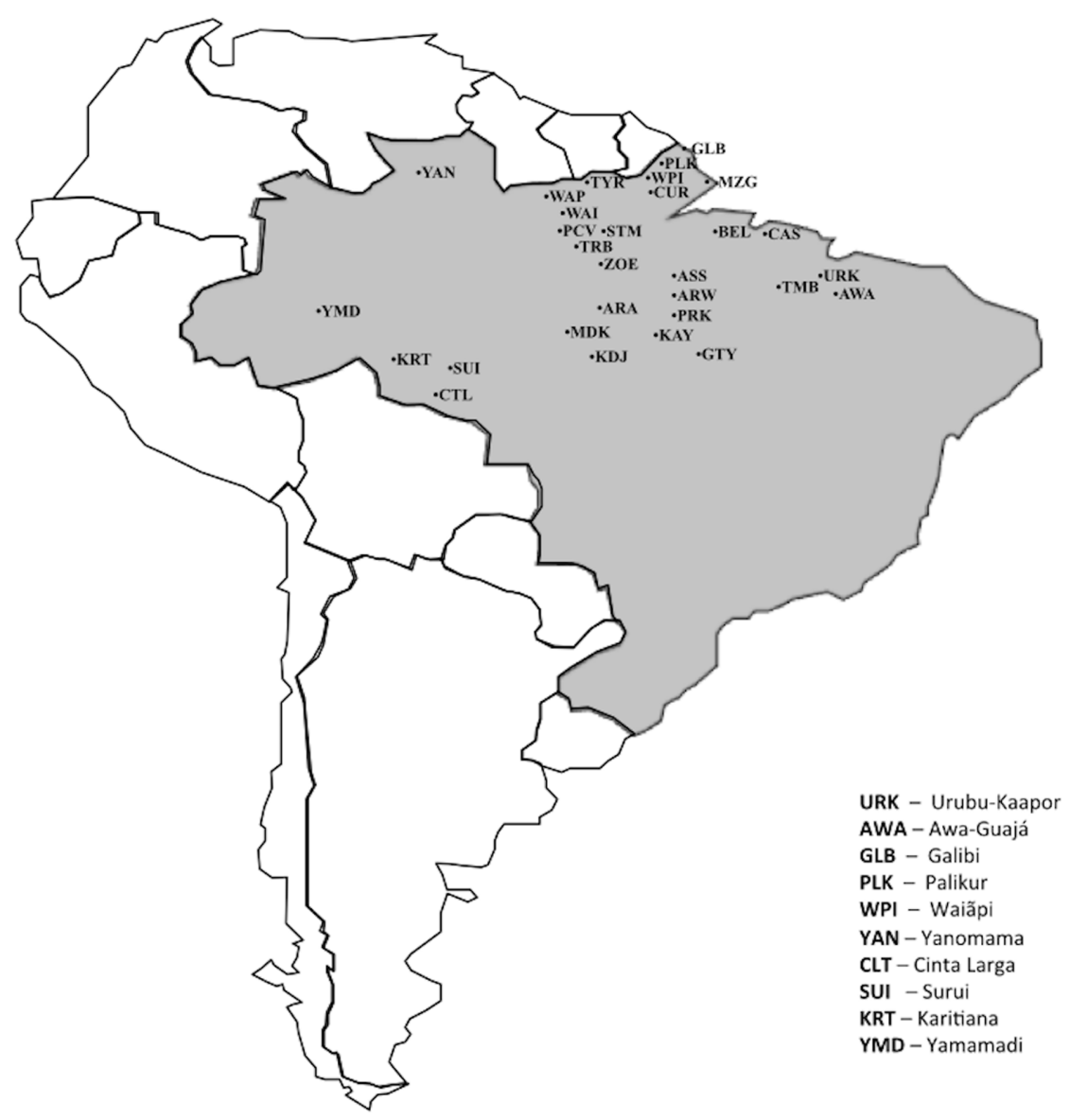

\section{STUDY POPULATIONS}

$\div$ Urban area

BEL - Belém

CAS - Castanhal

STM - Santarém

MZG - Mazagão

* Quilombo

PCV - Pacoval

TRB - Trombetas

CUR - Curiau

* Indian Groups

WAP - Waiana-Apalai

TYR - Tiriyó

ASS - Assurini

- Kuatinemo

- Trocará

ARA - Arara

- Kurambê

- Laranjal

- Iriri

GTY - Gorotyre

ARW - Araweté

PRK - Parakanã

MDK - Munduruku

ZOE - Zo'é

WAI - Wai-Wai

KDJ - Kendjam

TMB - Tembé

KAY - Kayapó

- Aukre

- Kubenkokre

- Pukani

- Kikretum

- Kokraimoro

- Kararaô

FIGURE 1 | Geographical location of the human populations investigated for HTLV, JCV, HHV-8, and Chlamydia infections (prepared by the authors and edited using Power Point for Mac).

Parakana, Aukre, Tembe, and Assurini), Maranhao (UrubuKaapor), and Rondonia (Surui), one Brazilian afro-descendant "quilombo" from the Rio Trombetas region in the West of the State of Para and from its capital, the city of Belem (Figure 1). JC virus was detected in urine samples using the amplification of $v p 1$ gene and IG region according to a previously described protocol (Cayres-Vallinoto et al., 2012). The amplified products of the IG region were used to construct the phylogenetic trees and subsequent relationships among the strains detected. Detailed methodological steps were previously described (Cayres-Vallinoto et al., 2012).

\section{HHV-8}

Antibodies to human herpes virus-8 (HHV-8) were investigated among four native Indian groups (Kararao, Arara Laranjal, Tiriyo, and Zo'e) from the Amazon region (Figure 1). An enzyme immune assay with four structural and non-structural antigens (Katano et al., 2000) was used. Nucleic acid extraction was performed in the positive samples in order to sequence region ORF26 and region 1 of the $k 1$ gene to confirm serological results and to prepare phylogenetic trees which allowed to describe the molecular subtypes of HHV-8. Detailed methodological steps were previously described (Chang et al., 1994; Cook et al., 1999; Ishak et al., 2007).

\section{Chlamydia trachomatis}

Antibodies to Chlamydia were detected in the blood samples of: (i) patients from a university public hospital (respiratory and cardiac disease) in the city of Belem, Para; (ii) subjects from two major urban communities (Santarem and Castanhal) of the State of Para; (iii) individuals from two isolated Afrodescendant communities located in Northern Brazil (Pacoval, State of Para, and Curiau, State of Amapa) who originated from runaway individuals during the slavery period; (iv) individuals from Mazagao, State of Amapa, a village originating from immigrants of North Africa; and (v) three native Indian groups from the State of Maranhao (Awa-Guaja), and the State of Para (Wayana-Apalai and Kokraimoro) (Figure 1). A commercial indirect immunofluorescence assay using serotype L2 of $C$. trachomatis as the antigen was used for the screening of antibodies to the genus Chlamydia. Positive samples were titrated and those with titers equal or greater than 512 were investigated to detect serological evidence of bacterium persistence (Conway et al., 1984; Lobos et al., 1996). 


\section{HTLV-2}

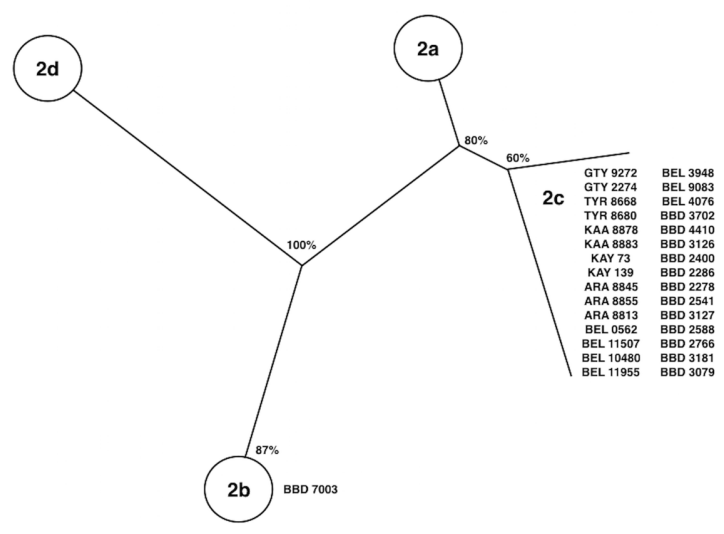

FIGURE 2 | Phylogenetic tree showing HTLV-2 subtypes isolated from native Indian communities from the Amazon region of Brazil [adapted from Ishak et al. (1995) and Vallinoto et al. (2002)].

Serum reactivity to specific serotypes of $C$. trachomatis was discriminated using a microimmunofluorescence assay with serially diluted samples to detect the most recent infection, as well as double or multiple infections. Detailed methodological steps were previously described (Wang and Grayston, 1974; Grayston and Wang, 1975; Treharne et al., 1983; Conway et al., 1984; Ishak et al., 1988, 1993, 2015; Campbell et al., 1990; Lobos et al., 1996; Ishak and Ishak, 2001).

\section{THE EVIDENCES OF HUMAN MIGRATION ACCOMPANIED BY INFECTIOUS AGENTS IN THE AMAZON REGION OF BRAZIL}

\section{HTLV}

The initial investigation of HTLV among Indian populations in the Amazon region of Brazil was based on retrospective seroepidemiological studies aiming to find previous infection markers of the virus among human populations residing in this particular area. Previously, HTLV-2 infection was shown to be present among few individuals of the Kayapo and Kraho villages (Maloney et al., 1992). Subsequently, our group described the serological and molecular epidemiology of HTLV infection among 18 native Indian tribes located in the Brazilian Amazon region, and the existence of a unique molecular subtype named HTLV-2c (Figure 2). This subtype is endemically distributed in a large geographical setting (more than 5 million $\mathrm{km}^{2}$ ) and maintained under continuous transmission (vertical and horizontally) among epidemiologically isolated human groups due to their physical, cultural, and linguistic barriers (Ishak et al., 1995; Eiraku et al., 1996). The virus was later confirmed in other Amerindian communities and in different groups (blood donors and HIV-1 infected patients) residing in the city of Belem, the largest urban area in the Amazon region (Vallinoto et al., 2002).
The geographical distribution of HTLV-2 around the world shows that in the Americas, the virus is present from North to South America in the molecular subtypes HTLV-2a (predominantly in urban areas) and HTLV-2b, predominantly among native Indians groups from North, Central, and South America (Heneine et al., 1991; Biglione et al., 1993; Ferrer et al., 1993; Levine et al., 1993; Switzer et al., 1995). The distribution of molecular subtype HTLV-2c follows another pattern and is largely spread among Amerindians from the Amazon region of Brazil. Human T-lymphotropic virus 2 has apparently emerged in the African continent and was brought to the Americas, crossing the Bering Strait probably 11,000-13,000 years ago (Switzer et al., 1996; Vallinoto et al., 2002). Archeological, anthropological, and genetic studies have shown that a wave of migration occurred apart from the Andean region, to the Amazon region in South America, which may have introduced HTLV-2c exclusively into the region and evolved independently from the other subtypes (Figure 3).

Once the virus reached its way into the community it was actively transmitted horizontally (via the sexual route) and maintained within epidemiologically closed communities using the vertical transmission from mother to child, a characteristic of retroviral persistent infections with integration of the viral nucleic acid into the host genome (Ishak et al., 1995, 2001; Vallinoto et al., 2002). The widespread distribution among indigenous populations with different linguistic and cultural backgrounds is the main support for the introduction and spreading of the virus in ancient populations. Genetic processes of fission and fusion of large and small communities, respectively, were probably responsible for the current widespread distribution of the virus. The presence of the virus in urban communities is a direct result of the extensive miscegenation of the Brazilian population which occurred during the colonization period. It is possible that the introduction of HTLV-2c is a consequence of an ancient process occurring over many generations. The lack of serological evidence of previous contact with HTLV in some groups suggests the occurrence of the founder effect and the introduction in urban areas as a recent event through sexual transmission (Ishak et al., 1995; Vallinoto et al., 2002).

More recently, the virus was detected in several major cities of Brazil, including Salvador (Barreto et al., 2014), Belo Horizonte (Catalan-Soares et al., 2005), Rio de Janeiro (Silva et al., 2002), São Paulo (Eiraku et al., 1996), and Porto Alegre (Renner et al., 2006). The wide distribution of the virus from North to South of the country is a result of a more recent spreading of the virus from the Indian communities to urban areas and, subsequently, into highly populated cities. The virus was also detected among Guarani Indians in the far South of Brazil, in the State of Parana (Menna-Barreto et al., 2005).

Brazil received large waves of migration around 100 years ago, in the beginning of the 20th century, from European nations (particularly from Portugal, Spain, and Italy) and at a smaller scale from Japan (Emmi, 2013). Our group was able to trace the migration and the introduction of a new virus, HTLV-1, into the Amazon region, following this more recent pathway. The virus is highly prevalent in the South of Japan (Yamashita et al., 


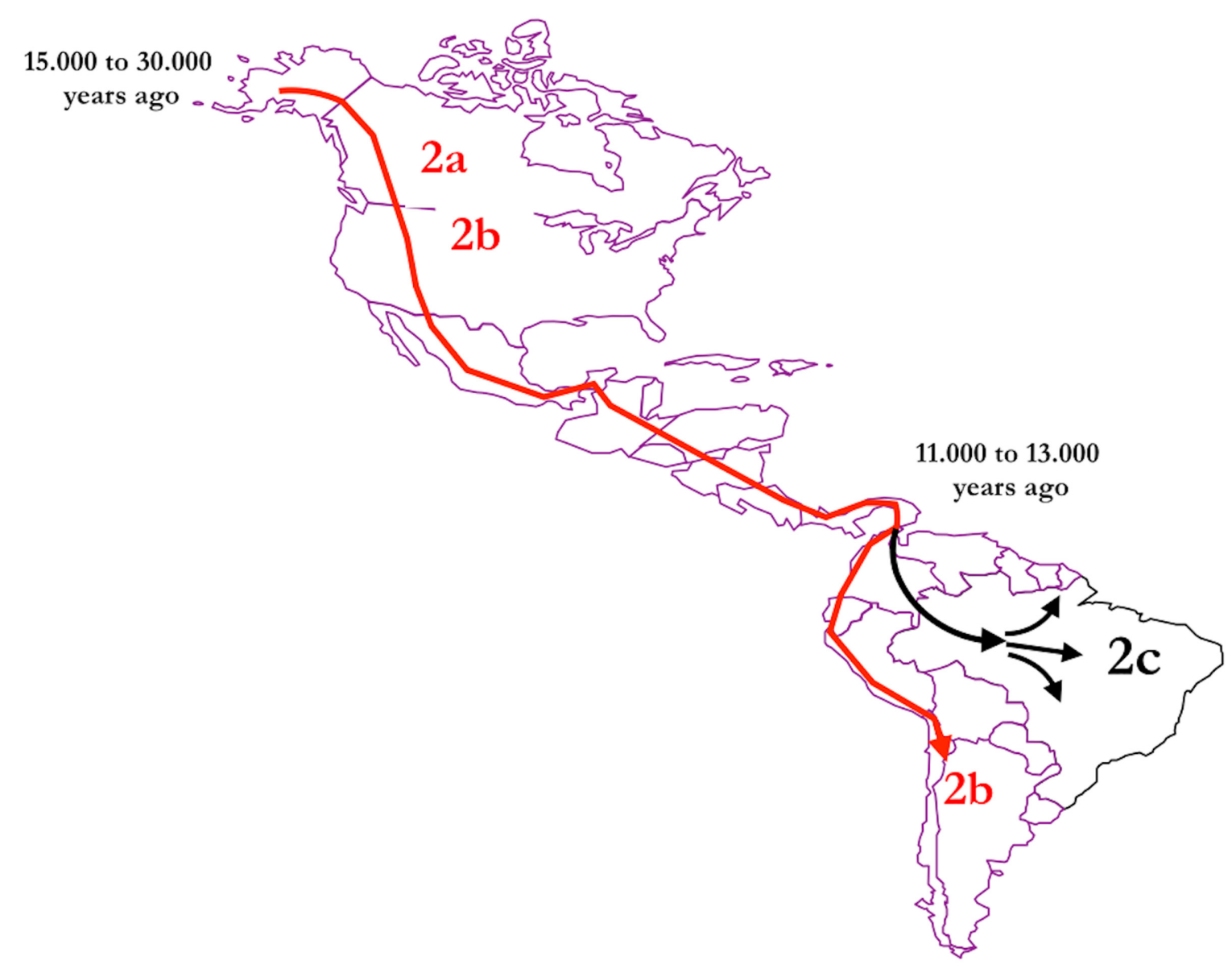

FIGURE 3 | Possible route of HTLV-2 dissemination and origin of HTLV-2c according to the ancient human migration in the American continent (prepared by the authors and edited using Power Point for Mac).

1999) and a great amount of Japanese immigrants were brought to the North of Brazil (State of Para) and were kept as a small epidemiologically closed community, with their original social, cultural, and behavior for decades. Human T-lymphotropic virus 1 was probably introduced in the Amazon region, on two different occasions during human colonization. In the first move, the African descendants brought the virus to Brazil during the slavery period and, more recently during a second wave of migration from Japan. The presence of HTLV-1, subtypes Transcontinental and Japanese, among immigrants living in a small rural city named Tome-Acu (Para State, Northern Brazil) was clearly characterized (Vallinoto et al., 2004; Figure 4). TomeAcu was a village settled by the Japanese immigrants for specific agricultural purposes (Emmi, 2013). The infected persons were three women who were more than 50 years old, and migrated from the Kyushu region, Southeast of Japan (Figure 5). The virus kept a similar genetic sequence as imported from Japan.

\section{JCV}

The finding of polyomavirus infections in the Amazon region helped to show the close association of migration routes of viruses and humans during their migration pathways. JC virus

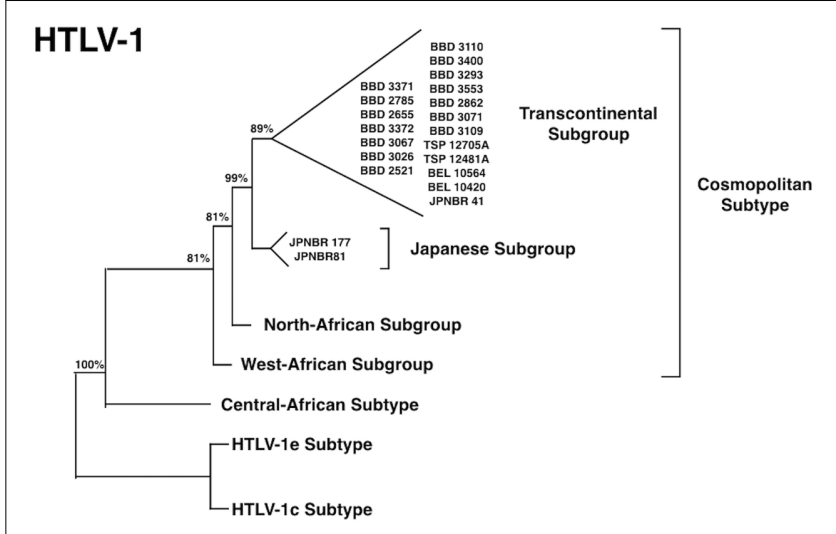

FIGURE 4 | Phylogenetic tree showing HTLV-1 subtypes isolated from Japanese immigrants in the Amazon region of Brazil [adapted from Vallinoto et al. (2004)].

was described in the following communities: types A (subtype EU), B (subtypes Af-2, African and MY, Asiatic), and C (subtype 


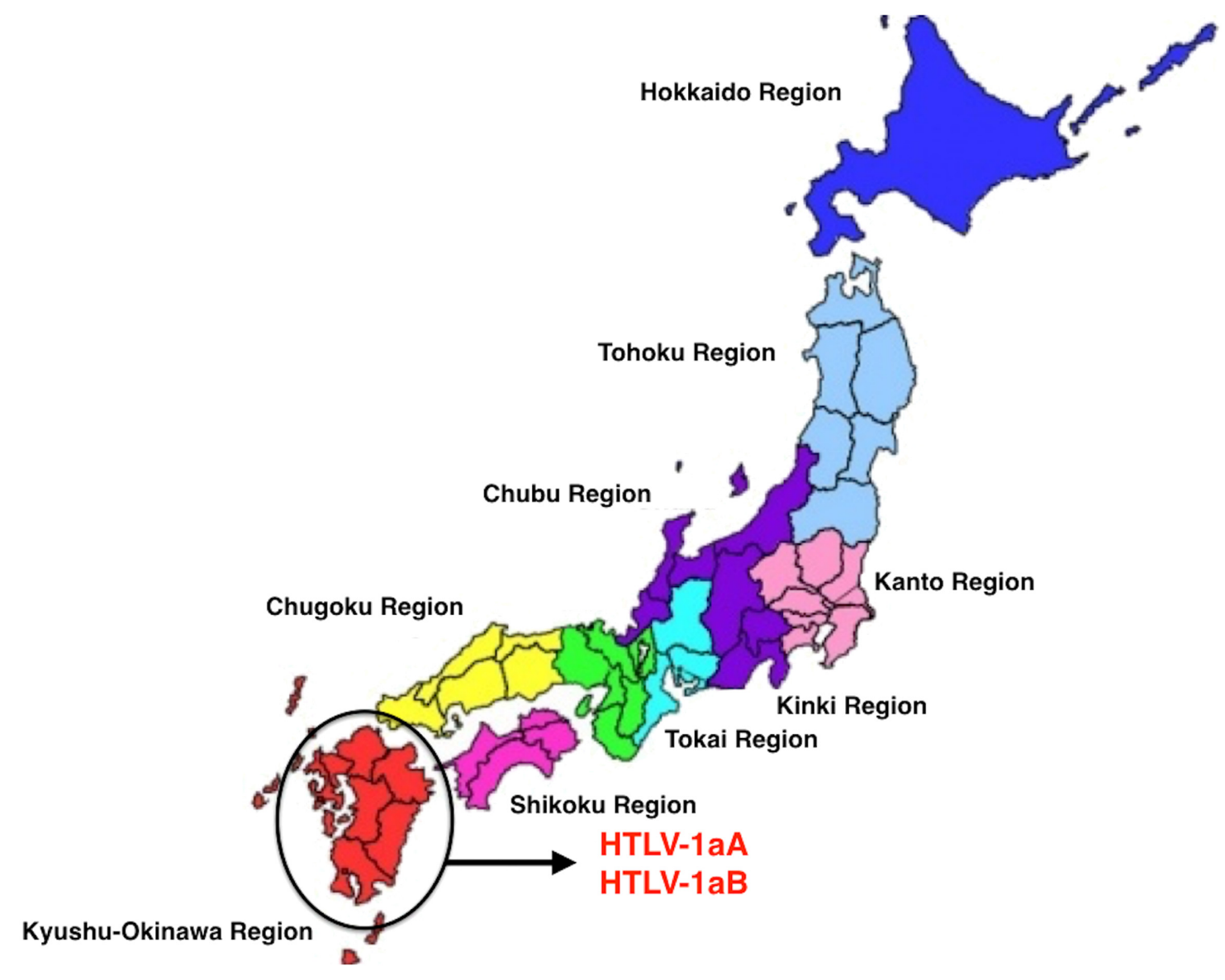

FIGURE 5 | Geographical origin of the Japanese immigrants who brought HTLV-1 subtypes, living in Para State, Northern Brazil (prepared by the authors and edited using Power Point for Mac).

Af-1) among subjects living in Belem; type B, subtypes Af-2 and MY, among Afro-Brazilians; and type B, subtype MY, within the Surui Indians (Figure 6; Cayres-Vallinoto et al., 2012).

Detection of the virus within an epidemiologically semiclosed population of native Indians reinforced the possibility of using JCV as a good marker for human migration in the Americas, including Canada and the United States (Stoner et al., 2000; Sugimoto et al., 2002). Prevalence studies of the virus in those countries are similar to those found in other countries of the Pacific and the Asian continent (Kunitake et al., 1995; Agostini et al., 1997; Stoner et al., 2000; Whiley et al., 2001, 2004; Sugimoto et al., 2002). In Belem, three ancestral types according to its geographical association were described: type A (found in Europe), type B (found in Africa and Asia), and type $\mathrm{C}$ (found in the African continent). This is in agreement with the historical miscegenetic process of the urban population of Brazil and the available information of the genetic composition of human populations living in Belem (Santos and Guerreiro, 1995; Rodrigues, 1999). The most frequent subtype (Af2) was present in samples from "mesticos," a phenotype characteristically related to a black ethnicity. This is an important observation when considering that most of the Af2 genotype evolved within the
African continent circa 50,000 years ago (Takasaka et al., 2006). Subtype MY from Belem was also detected among "mesticos," a common finding among native Amerindians (Zheng et al., 2003). MY and Af2 were detected in the Trombetas "quilombo."

The situation observed among urban areas, native Indians, and native Americans strongly suggests that JCV, type B, and subtype MY established persistent infections in humans and entered in a similar fashion as HTLV-2, into the Brazilian Amazonian population circa 10,000 years ago. However, a different route of JCV entry was probably more recent (200300 years ago) during the slavery trade into Brazil. A second spread occurred in the "quilombos," which occurred as early as in 1788 in the State of Para (Salles, 1998). This is shown by the extensive distribution of type B, subtype Af2 among the trihybrid groups of humans in the Amazon region of Brazil. Usually, a higher prevalence of JCV is observed in the Americas than on the African continent (Chima et al., 1998; Stoner et al., 2000), a possible consequence of the intense miscegenation of Afro-descendants in Brazil and in the United States. The HIV1 epidemic was also followed by a marked spreading of JCV among urban communities (Nali et al., 2012; Cayres-Vallinoto et al., 2016). 


\section{JCV}

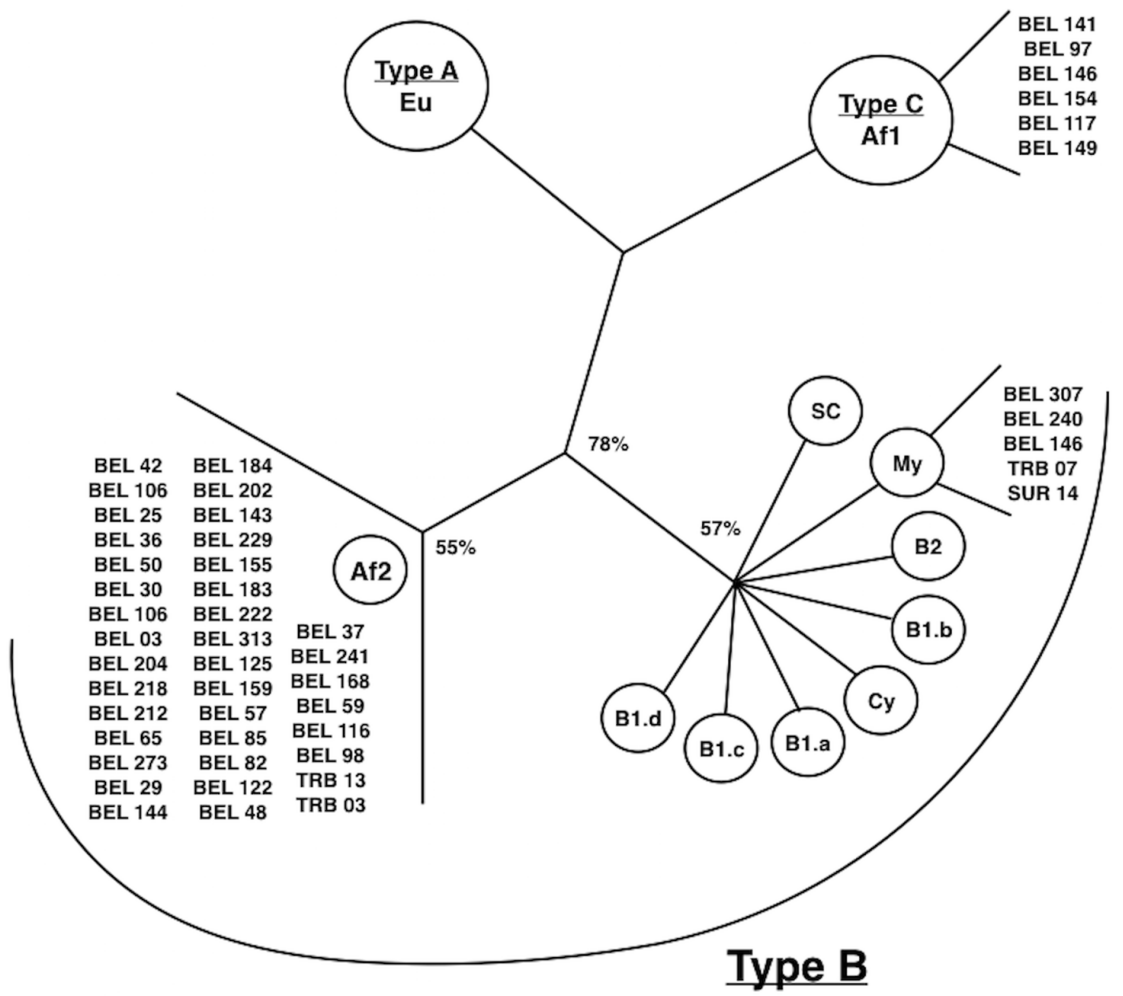

FIGURE 6 | Phylogenetic tree showing JCV subtypes isolated from Amazon populations. [adapted from Cayres-Vallinoto et al. (2012)].

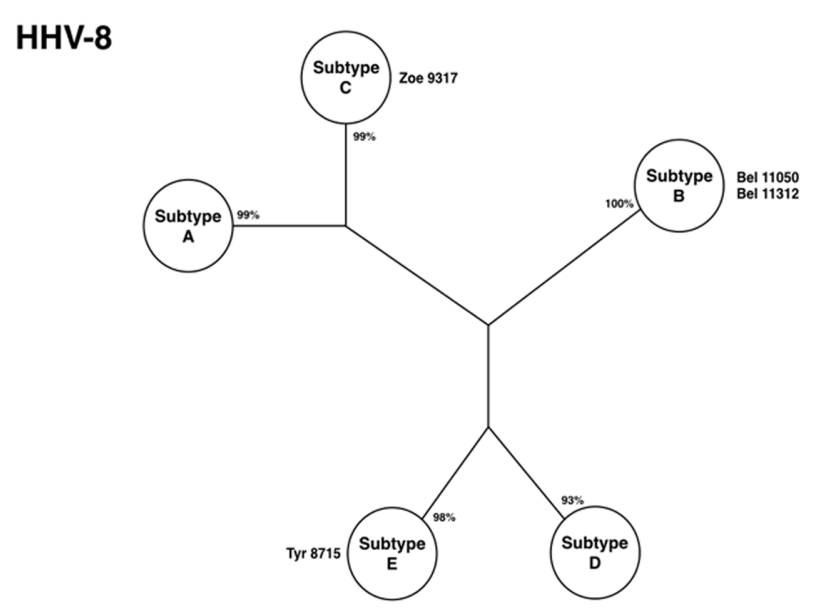

FIGURE 7 | Phylogenetic tree showing HHV-8 subtypes isolated from Amazon populations [adapted from Ishak et al. (2007)].

\section{HHV-8}

Human herpes virus-8 infections in the Amazon region showed a widespread agent both in urban and non-urban communities, including native Indians in Brazil, French Guiana, and Equador
(Freitas et al., 2002; Whitby et al., 2004; Cunha et al., 2005; Kazanji et al., 2005; Ishak et al., 2007). The high positive percentage levels of antibodies found in some investigated communities indicated that vertical transmission was occurring and playing an important role for the virus maintenance and spread, as a herpesvirus persistent infection. There was a sharp and steady constant rise in the age prevalence of antibodies seen in the Indian villages of Kararao, Arara Laranjal, Tiriyo, and Zo'e, followed by a decrease in the prevalence after the first 10 years of life.

Sequencing the VR1 region (gene $k 1$ ) identified diversity of HHV-8 subtypes among urban and native Indians. Subtypes E and $\mathrm{C}$ were described in the Tiriyo and the Zo'e, respectively (Figure 7). Human herpes virus-8, subtype E, was also described among two other Brazilian Indian communities (Arawete and Assurini), in French Guiana (Wayampi), and in Equador (Biggar et al., 2000; Whitby et al., 2004; Kazanji et al., 2005). It emerged as a unique molecular subtype among Amerindians of the Amazon region with different linguistic groups. Subtype $\mathrm{C}$ is commonly associated to patients with classical Kaposi sarcoma (KS), iatrogenic, and KS present in AIDS patients in Middle East and Asia (Zong et al., 1999), and its finding in an epidemiologically closed community in the Amazon region of Brazil was quite exquisite, considering that those persons have never left their villages nor had any relation with outsiders. 
The higher prevalence of HHV-8 among rural Amerindians than in urban areas, the presence of a diversity of molecular subtypes (three out of five, considering the urban areas), and the presence of a unique strain found solely within the Amazon region are strong evidence that the virus represents an ancient endemic infection of native Indians. Human herpes virus- 8 is another example of how viruses which establish persistence can also help to understand the mobility of humans around the world in their search for new areas for a better living.

\section{Chlamydia trachomatis}

The political organization of Brazil dates from the 1500s, starting as a colony of Portugal, but with several invasions throughout the centuries from other European countries, including Spain, Netherlands, and France. Several other waves of immigrants were also reported and some remain unclear. C. trachomatis, a widespread infection all over the world, is a bacterium used by our group to describe a more recent massive migration that occurred in the 18 th century.

The presence of serotype A of C. trachomatis has been detected by our group, indirectly on several occasions among urban and non-urban communities including an extensive search among native Indians in the Amazon region of Brazil (Ishak and Ishak, 2001; Ishak et al., 2015). More recently, reactivity to serotype A was also described among patients in six different groups tested (in an urban university hospital, in some major cities of the State of Para, among native Indians, one Afro-descendant community, and particularly, among one village in the State of Amapa, named Mazagao). The village of Mazagao was established during the 18th century as a consequence of a massive immigration movement (more than 1,000 Portuguese Catholics) from North Africa. These people emigrated from North Africa to escape Muslim persecution, following a religious war that occurred in their hometown, a place also called Mazagao.

Trachoma an eye infection and a severe inflammatory disease caused by $C$. trachomatis is associated with infections by serotype A, usually described to occur within a limited area in the Middle East and Northern Africa, serotypes B and C commonly described as cosmopolitan strains and serotype $B_{1}$ infecting North American Indians. The most probable explanation to establish the route of entry of serotype A into the Amazon region of Brazil was through the refugees from Mazagao. Since then, the bacterium was spread urban and non-urban populations elsewhere (through bad hygienic habits, poor conditions of living, and vectors among others). Curiously, serorreactivity to serotypes E and J, strains usually sexually transmitted, were seen exclusively within the Mazagao village.

\section{REFERENCES}

Agostini, H. T., Yanagihara, R., Davis, V., Ryschkewitsch, C. F., and Stoner, G. L. (1997). Asian genotypes of JC virus in Native Americans and in a Pacific Island population: markers of viral evolution and human migration. Proc. Natl. Acad. Sci. U.S.A. 94, 14542-14546. doi: 10.1073/pnas.94.26.14542

Barreto, F. K., Rego, F. F., Fonseca, L. M., Galvão-Castro-Filho, B., Araújo, T. H., Mota-Miranda, A. C., et al. (2014). Molecular characterization of the human T cell lymphotropic virus type 2 long terminal repeat region: a discussion about

\section{CONCLUSION}

The different methods by which infectious agents are detected in ancient specimens were used in a combined approach with archeology to detect past and ancient infections in order to improve the understanding of the origin, emergence, evolution, and spreading of viruses, bacteria, and other infectious agents. Similar methods were also used to describe recent emergence and introduction of infectious agents.

In our previous studies, HTLV-2, JCV, HHV-8, and C. trachomatis were described among Amerindian tribes, Afrodescendant communities, and in the trihybrid population living in the urban and non-urban areas of the Amazon region of Brazil. The presence of different and largely variable strains of those agents circulating in the region and infecting selected human host groups brought light to the association of the ethnic origin of the populations investigated. The molecular linkage of different strains to specific areas in the European, Asiatic, and African continents is excellent tools to highlight the role of infectious agents as markers for studying the early migration of human populations, reflecting their early and late history.

The present world situation of political instability in several countries is, again, causing a massive movement of humans from Haiti to Brazil and from the Middle East to Europe (and to a lesser extent to other continents). It is quite certain that we will soon observe the introduction and upsurge of viruses and other infectious agents into different geographical areas. The use of infectious agents capable of establishing persistence is of major importance as models to study their clinical interaction with humans and microbiological active surveillance will be necessary to follow up the present ongoing migratory wave.

\section{AUTHOR CONTRIBUTIONS}

All authors listed have made a substantial, direct and intellectual contribution to the work, and approved it for publication.

\section{FUNDING}

This work was supported in part by different grants from the CNPq, Japan Institutes of Health, National Institutes of Health, PRONEX/CNPq/FAPESPA, and PROPESP/ UFPA.

possible influences at viral gene expression. AIDS Res. Hum. Retroviruses 30, 92-96. doi: 10.1089/AID.2013.0181

Biggar, R. J., Whitby, D., Marshall, V., Linhares, A. C., and Black, F. (2000). Human herpesvirus 8 in Brazilian Amerindians: a hyperendemic population with a new subtype. J. Infect. Dis. 181, 1562-1568. doi: 10.1086/ 315456

Biglione, M., Gessain, A., Quiruelas, S., Fay, O., Taborda, M. A., Fernandez, E., et al. (1993). Endemic HTLV-II infection among Tobas and Mataco Amerindians from North Argentina. J. Acquir. Immune Defic. Syndr. 6, 631-633. 
Campbell, L. A., Kuo, C. C., and Grayston, J. T. (1990). Structural and antigenic analysis of Chlamydia pneumoniae. Infect. Immun. 58, 93-97.

Catalan-Soares, B., Barbosa-Stancioli, E. F., Alcantara, L. C., Carneiro-Proietti, A. B., Martins, M. L., Namen-Lopes, M. S., et al. (2005). HTLV-2 horizontal and vertical transmission in a family from a Brazilian urban area: seroepidemiological, clinical and molecular study. AIDS Res. Hum. Retroviruses 21, 521-526. doi: 10.1089/aid.2005.21.521

Cayres-Vallinoto, I. M., Vallinoto, A. C., Azevedo, V. N., Machado, L. F., Ishak, M., de, O. G., et al. (2012). Human JCV infections as a bio-anthropological marker of the formation of Brazilian Amazonian populations. PLoS ONE 7:e46523. doi: 10.1371/journal.pone.0046523

Cayres-Vallinoto, I. M., Vallinoto, A. C., Pena, G. P., Azevedo, V. N., Machado, L. F., Ishak, M., et al. (2016). JC virus/human immunodeficiency virus 1 coinfection in the Brazilian Amazonian region. Braz. J. Infect. Dis. 20, 360-364. doi: 10.1016/j.bjid.2016.05.005

Chang, Y., Cesarman, E., Pessin, M. L., Lee, F., Culpepper, J., Knowles, D. M., et al. (1994). Identification of herpesvirus-like DNA sequences in AIDS-associated Kaposi's sarcoma. Science 266, 1865-1869. doi: 10.1126/science.7997879

Chima, S. C., Ryschkewitsch, C. F., and Stoner, G. L. (1998). Molecular epidemiology of human polyomavirus JC in the Biaka Pygmies and Bantu of Central Africa. Mem. Inst. Oswaldo Cruz 93, 615-623. doi: 10.1590/S007402761998000500010

Conway, D., Glazener, C. M., Caul, E. O., Hodgson, J., Hull, M. G., Clarke, S. K., et al. (1984). Chlamydial serology in fertile and infertile women. Lancet 1, 191-193. doi: 10.1016/S0140-6736(84)92113-5

Cook, P. M., Whitby, D., Calabro, M. L., Luppi, M., Kakoola, D. N., Hjalgrim, H., et al. (1999). Variability and evolution of Kaposi's sarcoma-associated herpesvirus in Europe and Africa. AIDS 13, 1165-1176. doi: 10.1097/00002030199907090-00004

Cunha, A. M. G., Caterino-de-Araujo, A., Costa, S. C. B., Santos-Fortuna, E., Boa-Sorte, N. C. A., Gonçalves, M. S., et al. (2005). Increasing seroprevalence of human herpesvirus 8 (HHV-8) with age confirms HHV-8 endemicity in Amazon Amerindians from Brazil. J. Gen. Virol. 86, 2433-2437. doi: 10.1099/ vir.0.81087-0

Djelouadji, Z., Raoult, D., and Drancourt, M. (2011). Palaeogenomics of Mycobacterium tuberculosis: epidemic bursts with a degrading genome. Lancet Infect. Dis. 11, 641-650. doi: 10.1016/S1473-3099(11)70093-7

Drancourt, M., Aboudharam, G., Signoli, M., Dutour, O., and Raoult, D. (1998). Detection of 400-year-old Yersinia pestis DNA in human dental pulp: an approach to the diagnosis of ancient septicemia. Proc. Natl. Acad. Sci. U.S.A. 95, 12637-12640. doi: 10.1073/pnas.95.21.12637

Eiraku, N., Novoa, P., da Costa Ferreira, M., Monken, C., Ishak, R., da Costa Ferreira, O., et al. (1996). Identification and characterization of a new and distinct molecular subtype of human T-cell lymphotropic virus type 2. J. Virol. 70, 1481-1492.

Emmi, M. F. (2013). Um Século de Imigrações Internacionais na Amazônia Brasileira (1850-1950). Belém: Editora do Núcleo de Altos Estudos Amazônicos da Universidade Federal do Pará.

Ferrer, J. F., del Pino, N., Esteban, E., Sherman, M. P., Dube, S., Dube, D. K., et al. (1993). High rate infection with the human T-leukemia retrovirus type II in four Indian populations of Argentina. Virology 197, 576-584. doi: 10.1006/viro.1993. 1631

Fornaciari, G., Zavaglia, K., Giusti, L., Vultaggio, C., and Ciranni, R. (2003). Human papillomavirus in a 16th century mummy. Lancet 362, 1160. doi: 10.1016/S0140-6736(03)14487-X

Freitas, R. B., Freitas, M. R., and Linhares, A. C. (2002). Prevalence of human herpesvirus 8 antibodies in the population of Belem, Para, Brazil. Rev. Inst. Med. Trop. Sao Paulo 44, 309-313. doi: 10.1590/S0036-466520020006 00003

Glick, M., Trope, M., Bagasra, O., and Pliskin, M. E. (1991). Human immunodeficiency virus infection of fibroblasts of dental pulp in seropositive patients. Oral Surg. Oral Med. Oral Pathol. 71, 733-736. doi: 10.1016/00304220(91)90284-J

Grayston, J. T., and Wang, S. P. (1975). New knowledge of chlamydiae and the diseases they cause. J. Infect. Dis. 132, 87-105. doi: 10.1093/infdis/132.1.87

Heneine, W., Kaplan, J., Gracia, F., Lai, R., Roberts, B., Levine, P. H., et al. (1991). HTLV-II endemicity among Guaymi Indians in Panama. N. Engl. J. Med. 324, 565. doi: 10.1056/NEJM199102213240815
Ishak, M. O., Costa, M. M., Almeida, N. C., Santiago, A. M., Brito, W. B., Vallinoto, A. C., et al. (2015). Chlamydia trachomatis serotype A infections in the Amazon region of Brazil: prevalence, entry and dissemination. Rev. Soc. Bras. Med. Trop. 48, 170-174. doi: 10.1590/0037-8682-0038-2015

Ishak, M. O., and Ishak, R. (2001). Chlamydia infection impact among native Indian groups of the Brazilian Amazon region. Cad. Saude Publica 17, 385-396. doi: 10.1590/S0102-311X2001000200013

Ishak, M. O. G., Ishak, R., Cruz, A. C., Santos, D. E., and Salgado, U. (1993). Chlamydial infection in the Amazon region of Brazil. Trans. R. Soc. Trop. Med. Hyg. 87, 60-62. doi: 10.1016/0035-9203(93)90421-L

Ishak, M. O. G., Martins, R. N., Machado, P. R. L., de Souza, L. L. B., Machado, L. F. A., Azevedo, V. N., et al. (2007). High diversity of HHV-8 molecular subtypes in the Amazon region of Brazil: evidence of an ancient human infection. J. Med. Virol. 79, 1537-1544. doi: 10.1002/jmv.20995

Ishak, M. O. G., Mumtaz, G., Ishak, R., and Ridgway, G. (1988). Prevalence of antibodies to Chlamydia trachomatis in population groups of Brazil, England and Portugal. Rev. Inst. Med. Trop. São Paulo 30, 40-44. doi: 10.1590/S003646651988000100007

Ishak, R., Harrington, W. J. Jr., Azevedo, V. N., Eiraku, N., Ishak, M. O., Guerreiro, J. F., et al. (1995). Identification of human T cell lymphotropic virus type IIa infection in the Kayapo, an indigenous population of Brazil. AIDS Res. Hum. Retroviruses 11, 813-821. doi: 10.1089/aid.1995.11.813

Ishak, R., Ishak, M. O. G., Tsiquaye, K., and Cardoso, D. D. P. (1989). Soroepidemiologia retrospectiva do HIV-1. Rev. Inst. Med. Trop. São Paulo 31, 80-83. doi: 10.1590/S0036-46651989000200003

Ishak, R., Vallinoto, A. C., Azevedo, V. N., Lewis, M., Hall, W. W., and Guimarães Ishak, M. O. (2001). Molecular evidence of mother-to-child transmission of HTLV-IIc in the Kararao Village (Kayapo) in the Amazon region of Brazil. Rev. Soc. Bras. Med. Trop. 34, 519-525. doi: 10.1590/S0037-86822001000600004

Katano, H., Iwasaki, T., Baba, N., Terai, M., Mori, S., Iwamoto, A., et al. (2000). Identification of antigenic proteins encoded by human herpesvirus 8 and seroprevalence in the general population and among patients with and without Kaposi's sarcoma. J. Virol. 74, 3478-3485. doi: 10.1128/JVI.74.8.3478-3485.2000 Kazanji, M., Dussart, P., Duprez, R., Tortevoye, P., Pouliquen, J. F., Vandekerhove, J., et al. (2005). Serological and molecular evidence that human herpesvirus 8 is endemic among Amerindians in French Guiana. J. Infect. Dis. 192, 1525-1529. doi: 10.1086/491744

Kunitake, T., Kitamura, T., Guo, J., Tagushi, F., Kawabe, K., and Yogo, Y. (1995). Parent-to-children transmission is relatively common in the spread of the human polyomavirus JC virus. J. Clin. Microbiol. 33, 1448-1451.

Levine, P. H., Jacobson, S., Elliot, R., Cavallero, A., Colclough, G., Dorry, C., et al. (1993). HTLV-II infection in Florida Indians. AIDS Res. Hum. Retroviruses 9, 123-127. doi: 10.1089/aid.1993.9.123

Li, H. C., Fujiyoshi, T., Lou, H., Yashiki, S., Sonoda, S., Cartier, L., et al. (1999). The presence of ancient human T-cell lymphotropic virus type I provirus DNA in an Andean mummy. Nat. Med. 5, 1428-1432. doi: 10.1038/71006

Lobos, T., Moreno, R. B., Saldias, F. P., Cartagena, C. S., and Ferres, M. G. (1996). Seroprevalencia de infección por Chlamydia pneumoniae en población sana de Santiago de Chile. Rev. Chil. Enfermid. Resp. 12, 145-150.

Machado, L. F., Vallinoto, A. C., Souza, M. I., Azevedo, V. N., Ishak, M. O., and Ishak, R. (2006). Serological and molecular typing of HIV type 1 infection in the Tiriyo tribe, a native Indian community of the Amazon region of Brazil. AIDS Res. Hum. Retroviruses 22, 1267-1270. doi: 10.1089/aid.2006.22.1267

Maloney, E. M., Biggar, R. J., Neel, J. V., Taylor, M. E., Hahn, B. H., Shaw, G. M., et al. (1992). Endemic human T cell lymphotropic virus type II infection among isolated Brazilian Amerindians. J. Infect. Dis. 166, 100-107. doi: 10.1093/infdis/ 166.1.100

Menna-Barreto, M., Bender, A. L., Bonatto, S. L., Freitas, L. B., Salzano, F. M., Tsuneto, L. T., et al. (2005). Human T-cell lymphotropic virus type II in Guarani Indians, Southern Brazil. Cad. Saude Publica 21, 1947-1951. doi: 10.1590/ S0102-311X2005000600045

Nali, L. H., Centrone Cde, C., Urbano, P. R., Penalva-de-Oliveira, A. C., Vidal, J. E., Miranda, E. P., et al. (2012). High prevalence of the simultaneous excretion of polyomaviruses JC and BK in the urine of HIV-infected patients without neurological symptoms in São Paulo, Brazil. Rev. Inst. Med. Trop. Sao Paulo 54, 201-205. doi: 10.1590/S0036-46652012000400004

Nunes, H. M., Monteiro, M. R. C. C., and Soares, M. C. P. (2007). Prevalência dos marcadores sorológicos dos vírus das hepatites B e D na área indígena 
Apyterewa, do grupo Parakanã, Pará, Brasil. Cad. Saúde Pública 23, 2756-2766. doi: 10.1590/S0102-311X2007001100023

Raoult, D., Aboudharam, G., Crubezy, E., Larrouy, G., Ludes, B., and Drancourt, M. (2000). Molecular identification by "suicide PCR" of Yersinia pestis as the agent of medieval black death. Proc. Natl. Acad. Sci. U.S.A. 97, 12800-12803. doi: $10.1073 /$ pnas.220225197

Raoult, D., and Drancourt, M. (2008). Paleomicrobiology - Past Human Infections. Berlin: Springer.

Reid, A. H., Fanning, T. G., Hultin, J. V., and Taubenberger, J. K. (1999). Origin and evolution of the 1918 Spanish influenza virus hemagglutinin gene. Proc. Natl. Acad. Sci. U.S.A. 96, 1651-1656. doi: 10.1073/pnas.96.4.1651

Renner, J. D., Laurino, J. P., Menna-Barreto, M., and Schmitt, V. M. (2006). Molecular evidence of HTLV-II subtype B among an urban population living in South Brazil. AIDS Res. Hum. Retroviruses 22, 301-306. doi: 10.1089/aid.2006. 22.301

Rodrigues, J. D. (1999). Análise da Variabilidade de 11 Sistemas de Microssatélites na População de Belém-PA. Doctoral dissertation, Universidade Federal do Pará, Belém.

Salles, V. (1998). O Negro no Pará sob o Regime de Escravidão. Belém: SECULT Press.

Santos, A. K., Ishak, M. O., Santos, S. E., Guerreiro, J. F., and Ishak, R. (1995). A possible correlation between the host genetic background in the epidemiology of hepatitis B virus in the Amazon region of Brazil. Mem. Inst. Oswaldo Cruz 90, 435-442. doi: 10.1590/S0074-02761995000400001

Santos, S. E. B., and Guerreiro, J. F. (1995). The indigenous contribution to the formation of the population of the Brazilian Amazon Region. Braz. J. Genet. 18, 311-315.

Silva, E. A., Otsuki, K., Leite, A. C., Alamy, A. H., Sá-Carvalho, D., Vicente, A. C. (2002). HTLV-II infection associated with a chronic neurodegenerative disease: clinical and molecular analysis. J. Med. Virol. 66, 253-257. doi: 10.1002/jmv. 2138

Siravenha, L. G., Siravenha, L. Q., Madeira, L. D., Oliveira-Filho, A. B., Machado, L. F., Martins Feitosa, R. N., et al. (2016). Detection of HCV persistent infections in the dental pulp: a novel approach for the detection of past and ancient infections. PLoS ONE 11:e0165272. doi: 10.1371/journal.pone.0165272.

Spigelman, M., and Lemma, E. (1993). The use of the polymerase chain reaction (PCR) to detect Mycobacterium tuberculosis in ancient skeletons. Int. J. Osteoarchaeol. 3, 137-143. doi: 10.1002/oa.1390030211

Stoner, G. L., Jobes, D. V., Cobo, M. F., Agostini, H. T., Chima, S. C., and Ryschkewitsch, C. F. (2000). JC virus as a marker of human migration to the Americas. Microbes Infect. 2, 1905-1911. doi: 10.1016/S1286-4579(00)01339-3

Sugimoto, C., Hasegawa, M., Zheng, H. Y., Demenev, V., Sekino, Y., Kojima, K., et al. (2002). JC virus strains Indigenous to Northeastern Siberians and Canadian Inuits are unique but evolutionally related to those distributed throughout Europe and Mediterranean areas. J. Mol. Evol. 55, 322-335. doi: 10.1007/s00239-001-2329-2

Switzer, W. M., Black, F. L., Pieniazek, D., Biggar. R. J., Lal, R. B., and Heneine, W. (1996). Endemicity and phylogeny of the human T cell lymphotropic virus type II subtype A from the Kayapo Indians of Brazil: evidence for limited regional dissemination. AIDS Res. Hum. Retroviruses 12, 635-640. doi: 10.1089/aid.1996. 12.635

Switzer, W. M., Owen, S. M., Pieniazek, D., Nerurkar, V., Duenas-Barajas, E., Heneine, W., et al. (1995). Molecular analysis of human T-cell lymphotropic virus subtype II from Wayu Indians of Colombia demonstrates two subtypes of HTLV-IIb. Virus Gene 10, 153-162. doi: 10.1007/BF01702596

Takasaka, T., Kitamura, T., Sugimoto, C., Guo, J., Zheng, H. Y., and Yogo, Y. (2006). Phylogenetic analysis of major African genotype (Af2) of JC virus: implications for origin and dispersals of modern Africans. Am. J. Phys. Anthropol. 129, 465-472. doi: 10.1002/ajpa.20208

Treharne, J. D., Forsey, T., Thomas, B. J. (1983). Chlamydial serology. Br. Med. Bull. 39, 194-200. doi: 10.1093/oxfordjournals.bmb.a071815

Vallinoto, A. C. R., Ishak, M. O. G., Azevedo, V. N., Vicente, A. C. P., Otsuki, K., Hall, W. W., et al. (2002). Molecular epidemiology of human T-lymphotropic virus type II infection in Amerindian and urban populations of the Amazon region of Brazil. Hum. Biol. 74, 633-644. doi: 10.1353/hub.2002.0059

Vallinoto, A. C. R., Muto, N. A., Pontes, G. S., Machado, L. F. A., Azevedo, V. N., Santos, S. E. B., et al. (2004). Serological and molecular evidence of HTLV-I infection among japanese immigrants living in the Amazon region of Brazil. Jpn. J. Infect. Dis. 57, 156-159.

Wang, S. P., and Grayston, J. T. (1974). Human serology in Chlamydia trachomatis infection with microimmunofluorescence. J. Infect. Dis. 130, 388-397. doi: 10.1093/infdis/130.4.388

Whiley, D. M., Arden, K. E., Mackay, I. M., Syrmis, M. W., Sloots, T. P. (2004). Simultaneous detection and differentiation of human polyomaviruses JC and BK by a rapid and sensitive PCR-ELAHA assay and a survey of the JCV subtypes within an Australian population. J. Med. Virol. 72, 467-472. doi: 10.1002/jmv. 20005

Whiley, D. M., Mackay, I. M., and Sloots, T. P. (2001). Detection and differentiation of human polyomaviruses JC and BK by LightCycler PCR. J. Clin. Microbiol. 39, 4357-4361. doi: 10.1128/JCM.39.12.4357-4361.2001

Whitby, D., Marshall, V. A., Bagni, R. K., Wang, C. D., Gamache, C. J., Guzman, J. R., et al. (2004). Genotypic characterization of Kaposi's sarcoma-associated herpesvirus in asymptomatic infected subjects from isolated populations. J. Gen. Virol. 85, 155-163. doi: 10.1099/vir.0.19465-0

Yamashita, M., Veronesi, R., Menna-Barreto, M., Harrington, W. J. Jr., Sampio, C., Brites, C., et al. (1999). Molecular epidemiology of human T-cell leukemia virus type I (HTLV-1) Brazil: the predominant HTLV-1s in South America differ from HTLV-ls of Japan and Africa, as well as those of Japanese immigrants and their relatives in Brazil. Virology 261, 59-69.

Zaninovic, V., Sanzon, F., Lopez, F., Velandia, G., Blank, A., Blank, M., et al. (1994). Geographic independence of HTLV-I and HTLV- II foci in the Andes Highland, the Atlantic Coast, and the Orinoco of Columbia. AIDS Res. Hum. Retroviruses 10, 97-105. doi: 10.1089/aid.1994.10.97

Zheng, H. Y., Sugimoto, C., Hasegawa, M., Kobayashi, N., Kanayama, A., Rodas, A., et al. (2003). Phylogenetic relationships among JC virus strains in Japanese/Koreans and Native Americans speaking Amerind or Na-Dene. J. Mol. Evol. 56, 18-27. doi: 10.1007/s00239-002-2376-3

Zong, J. C., Ciufo, D. M., Alcendor, D. J., Wan, X., Nicholas, J., Browning, P. J., et al. (1999). High-level variability in the ORF-K1 membrane protein gene at the left end of the Kaposi's sarcoma-associated herpesvirus genome defines four major virus subtypes and multiple variants or clades in different human populations. J. Virol. 73, 4156-4170.

Conflict of Interest Statement: The authors declare that the research was conducted in the absence of any commercial or financial relationships that could be construed as a potential conflict of interest.

Copyright (C) 2017 Ishak, Machado, Cayres-Vallinoto, Guimarães Ishak and Vallinoto. This is an open-access article distributed under the terms of the Creative Commons Attribution License (CC BY). The use, distribution or reproduction in other forums is permitted, provided the original author(s) or licensor are credited and that the original publication in this journal is cited, in accordance with accepted academic practice. No use, distribution or reproduction is permitted which does not comply with these terms. 